\title{
Pivotal role of NF-KB in cellular senescence of experimental pituitary tumours
}

\author{
Bethania Mongi-Bragato1,2, Ezequiel Grondona1,2, Liliana del Valle Sosa1,2, Natacha Zlocowski1,2, Ana Clara Venier1,2, \\ Alicia Inés Torres ${ }^{1,2}$, Alexandra Latini³, Rodrigo Bainy Leal4, Silvina Gutiérrez ${ }^{1,2}$ and Ana Lucía De Paul1,2 \\ 1Universidad Nacional de Córdoba, Facultad de Ciencias Médicas, Centro de Microscopía Electrónica, Córdoba, Argentina \\ ${ }^{2}$ Consejo Nacional de Investigaciones Científicas y Técnicas, Instituto de Investigaciones en Ciencias de la Salud (INICSA), Córdoba, Argentina \\ ${ }^{3}$ Laboratório de Bioenergética e Estresse Oxidativo - LABOX, Departamento de Bioquímica, Universidade Federal de Santa Catarina, Campus \\ Universitário, Córrego Grande, Florianópolis, Brasil \\ 4Departamento de Bioquímica e Programa de Pós-graduação em Bioquímica, Centro de Ciências Biológicas, Universidade Federal de Santa Catarina, \\ Florianópolis, Santa Catarina, Brasil
}

Correspondence should be addressed to A L De Paul: adepaul@cmefcm.uncor.edu

\begin{abstract}
The molecular mechanisms underlying the capability of pituitary tumours to avoid unregulated cell proliferation are still not well understood. However, the NF-кB transcription factor, which is able to modulate not only cellular senescence but also tumour progression, has emerged as a targeted candidate. This work was focused on the NF-кB role in cellular senescence during the progression of experimental pituitary tumours. Also, the contribution of the signalling pathways in senescence-associated NF- $\mathrm{kB}$ activation and the senescence-associated secretory phenotype (SASP) and pro-

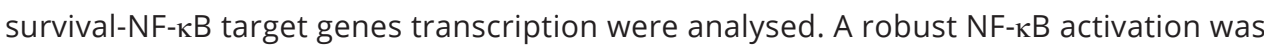
seen at E20-E40 of tumour development accompanied by a marked SA- $\beta$-Gal co-reactivity in the tumour pituitary parenchyma. The induction of TNF $\alpha$ and IL1- $\beta$ as specific SASPrelated NF- $\mathrm{KB}$ target genes as well as $\mathrm{BCl}-2$ and $\mathrm{BCl}-\mathrm{xl}$ pro-survival genes was shown to be accompanied by increases in the p-p38 MAPK protein levels, starting at the E20 stage and strengthening from 40 to 60 days of tumour growth. It is noteworthy that p-JNK displayed a similar pattern of activation during pituitary tumour development, while p-AKT and p-ERK1/2 were downregulated. By employing a pharmacological strategy to abrogate NF-kB activity, we demonstrated a marked reduction in SA- $\beta$-Gal activity and a slight decrease in Ki67 immunopositive cells after NF-kB blockade. These results suggest a central role for NF-кB in the regulation of the cellular senescence programme, leading to the strikingly benign intrinsic nature of pituitary adenomas.
\end{abstract}

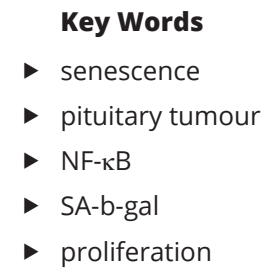

Journal of Endocrinology (2020) 245, 179-191

\section{Introduction}

The pituitary gland, the master regulator of homeostatic balance, responds in a dynamic manner to constantly changing hormonal and metabolic environments. However, an imbalance in the response to endogenous and exogenous signals can lead to hyperplasia and an excess in hormonal secretion, usually associated with adenoma formation. Pituitary tumours are usually benign neoplasms (Maiza \& Caron 2009) and rarely undergo malignant transformation, with the latter occurring in around $0.2 \%$ or less of all clinical cases (Scheithauer et al. 2006). 
Relevant evidence associated premature cell senescence mechanisms with the features of pituitary adenomas (Chesnokova et al. 2007, 2008), a process conceived as a tumour suppressive mechanism (Melmed 2011, Campisi \& Robert 2014).

Cellular senescence is a programme activated in response to damage and stress (Lopez-Otin et al. 2013), being characterized by high levels of senescence associated $\beta$-galactosidase activity (SA- $\beta$-Gal) (Lee et al. 2006) and p16 $6^{\mathrm{INK} 4 \mathrm{~A}}$ and $\mathrm{p} 21^{\mathrm{CIP} 1}$ expression (Kuilman et al. 2010). Furthermore, this process is also associated with a robust pro-inflammatory secretome (Chien et al. 2011, Hernandez-Segura et al. 2018), the so-called SASP (Coppe et al. 2008, Kuilman and Peeper 2009). In this scenario, the nuclear factor kappa B (NF-kB) signalling pathway has been proposed to control SASP production (Freund et al. 2011, Salminen et al. 2012), with a causal role suggested in the promotion of cellular senescence (Chien et al. 2011). The contribution of NF-kB in cellular senescence has been previously demonstrated (Rovillain et al. 2011, Liu et al. 2012), and MEK/ERK signalling has been linked to NF-kB activation and pro-inflammatory cytokine expression during this cellular process (Acosta et al. 2008). Related to this, p38 MAPK activation is sufficient to induce the SASP phenotype and promote cell growth arrest by activating p53 and p16 (Wang et al. 2002, Kwong et al. 2009, Freund et al. 2011). Moreover, c-Jun $\mathrm{N}$-terminal kinase (JNK) signalling is strongly activated by components of senescence secretome, such as TNF $\alpha$ and IL-1, and is also required for p53 activation in response to oncogenic stress (Schramek et al. 2011). In addition, the PI3K/Akt pathway can also stimulate NF- $\mathrm{BB}$ activation through the IKK complex (Ozes et al. 1999). However, the role of NF- $\mathrm{kB}$ as a tumour suppressor or promoter is still unclear. Although the NF-kB-driven cytokines may reinforce senescent cell-cycle arrest (Acosta et al. 2008, Rovillain et al. 2011), they have been reported to be associated with cell proliferation and tumour progression (Pikarsky et al. 2004, Karin 2006). Moreover, even though, NF- $\mathrm{kB}$ was found to be up-regulated in human pituitary adenomas (Chen et al. 2015), with its pharmacological inhibition reducing cell viability in the GH3 pituitary cell line (Vender et al. 2008), the role of this key transcription factor in pituitary cellular senescence has not yet been elucidated. Thus, considering the controversial role of the NF- $\kappa \mathrm{B}$ pathway in tumorigenesis, this study was focussed on the contribution of NF- $\mathrm{KB}$ activation in cellular senescence during in vivo experimental pituitary tumour development.

\section{Materials and methods}

\section{Animals and experimental model}

Three-month-old Wistar strain male rats were maintained at controlled temperature $\left(21 \pm 3^{\circ} \mathrm{C}\right)$ and lighting conditions (14 h light:10 h darkness cycle), with free access to commercial laboratory chow and tap water. As exogenous estrogen excess induces pituitary tumours (Asa \& Ezzat 2009, Sabatino et al. 2015, 2018), animals were treated with estradiol benzoate (EB, $10 \mathrm{mg}$ ) (Sigma Aldrich) for 10, 20, 40, and 60 days (E10, E20, E40, and E60) with EB being implanted subcutaneously in slow releasing silastic brand capsules (Dow Corning, Medical grade, Midland, MI, USA). Control group were implanted with empty capsules. Animals belonging to the different experimental groups were killed by decapitation, and fresh pituitary samples were collected and processed for the different experimental approaches. Animals were kept in accordance with the Guide for the Care and Use of Laboratory Animals, published by the United States National Institutes of Health (1996), with the experimental designs being approved by the Institutional Animal Care Committee of the School of Medicine, National University of Córdoba.

\section{Pyrrolidinedithiocarbamate administration protocol}

To assess the role of NF-kB on pituitary tumour development, the potent NF-kB inhibitor pyrrolidinedithiocarbamate was used (PDTC; Sigma-Aldrich) (Liu et al. 1999, Cuzzocrea et al. 2002, Miao et al. 2017, Yang etal. 2017) according to the following experimental design. Animals were randomly divided into four experimental groups $(n=5)$, referred to as control, E20, PDTC, and PDTC-E20. Rats from E20 and PDTC-E20 were implanted subcutaneously with $10 \mathrm{mg}$ EB for 20 days as described above, with animals from the control and PDTC groups being implanted with empty capsules. At the same time, PDTC and PDTC-E20 received daily intraperitoneal injections of the NF- $\mathrm{\kappa B}$ inhibitor $(50 \mathrm{mg} / \mathrm{kg}$ ) for 20 days, while control and E20 received sterile saline injections. Body weight, water, and food intake were periodically measured. At the end of treatments, animals from all groups were simultaneously killed, and fresh pituitaries were photographed in situ, weighed after collection, and processed for the different experiments.

\section{Cellular fractionation}

Subcellular fractionation was performed as previously described (Mongi-Bragato etal.2016). Briefly, pituitaries were (c) 2020 Society for Endocrinology Published by Bioscientifica Ltd. Printed in Great Britain 
homogenized in cytoplasmic extract buffer (10 mM HEPES $\mathrm{pH}=7.5,60 \mathrm{mM} \mathrm{KCl}, 1 \mathrm{mM}$ EDTA, $1 \mathrm{mM}$ dithiothreitol (DTT), $1 \mathrm{mM} \mathrm{NaVO}, 1 \mathrm{mM}$ phenylmethanesulfonyl fluoride (PMSF), $1 \mathrm{\mu g} / \mathrm{mL}$ aprotinin, $1 \mathrm{\mu g} / \mathrm{mL}$ leupeptin, $1 \mu \mathrm{g} / \mathrm{mL}$ pepstatin, and $0.075 \% \mathrm{NP} 40 \mathrm{v} / \mathrm{v}$ ) and centrifuged at $2000 \mathrm{~g}$ for $5 \mathrm{~min}$ at $4^{\circ} \mathrm{C}$ to pellet the nuclear fraction. Supernatants were centrifuged at $10,000 \mathrm{~g}$ for $10 \mathrm{~min}$ at $4^{\circ} \mathrm{C}$, and the resulting supernatants were used as cytoplasmic extracts. Then, the nuclear pellets were resuspended in nuclear extract buffer $(20 \mathrm{mM}$ Tris $\mathrm{HCl} \mathrm{pH}=8,420 \mathrm{mM}$ $\mathrm{NaCl}, 60 \mathrm{mM} \mathrm{KCl}, 1 \mathrm{mM}$ EDTA, $1 \mathrm{mM} \mathrm{NaVO}_{4}, 1 \mathrm{mM}$ PMSF, $25 \%$ glycerol v/v, $1 \mu \mathrm{g} / \mathrm{mL}$ aprotinin, $1 \mu \mathrm{g} / \mathrm{mL}$ leupeptin, and $1 \mu \mathrm{g} / \mathrm{mL}$ pepstatin), and centrifuged at 10,000 $\boldsymbol{g}$ for $10 \mathrm{~min}$ at $4^{\circ} \mathrm{C}$. The resulting supernatants were used as nuclear extracts, with aliquots of each sample being used for total protein quantification according to the Bradford method (Bio-Rad Protein Assay, Bio-Rad).

\section{Western blotting analysis}

Protein $(40 \mu \mathrm{g})$ extracts were separated by SDS-PAGE and transferred to nitrocellulose membranes. Blocking was performed using 5\% BSA (w/v) in T-TBS, and membranes were incubated overnight at $4^{\circ} \mathrm{C}$ with the corresponding primary antibody: anti-NF-kB p65 (RelA; 1:700), antitotal (t)-ERK (1:2000), anti-IкB $\alpha$ (1:300), or anti-p53 (1:200) (Santa Cruz Biotechnology); anti-phosphorylated (p)-RelA S536 (1/500), anti-p-ERK 1/2 (1:700), anti-p-Akt (1:500), anti-t-Akt (1:2000), anti-p-JNK (1:1000), antip-IKK $\alpha$ S176/ß S180 (1:300), anti-Lamin B (1:500), or anti- phosphorylated Histone H2AX (p- $\gamma \mathrm{H} 2 \mathrm{AX})(1 / 2000)$ (Cell Signaling); anti-p-p38 MAPK (1:10,000, Millipore), anti-t-p38 MAPK $(1: 10,000)$, anti-t-JNK (1:5000), or anti- $\alpha$-Tubulin (1:2000) (Sigma-Aldrich). After washing, membranes were incubated with a peroxidase-conjugated (HRP) goat anti-rabbit (1:5000; Bio-Rad), goat anti-mouse (1:3000; Jackson Laboratories), or mouse anti-goat (1:2000, Santa Cruz Biotechnology) and signals revealed with an ECL detection system (Amersham Biosciences). Emitted light was captured on Hyperfilm (Amersham Pharmacia Biotech). The $\alpha$-Tubulin and Lamin B antibodies were used as appropriate loading controls from cytosolic and nuclear extracts, respectively, and values were expressed as the percentage of the control group. Semi-quantitative signals were derived from the densitometric analysis using Image J software (v1.51; National Institutes of Health).

\section{Immunohistochemistry}

To assess SA- $\beta$-Gal detection as well as RelA and Ki67 staining, pituitaries were placed in Crioplast (Biopack,
Buenos Aires, Argentina), immersed in liquid nitrogen, and stored at $-80^{\circ} \mathrm{C}$. Sections were cut in a cryostat (CM1510S, Leica Microsystems, Wetzlar, Germany) and mounted on positively charged microscope slides. Then, pituitary cryosections $(7 \mu \mathrm{m})$ from control, tumour, and PDTC-treated animals were processed for RelA and Ki67 detection. Briefly, pituitary sections were fixed in absolute methanol, treated with $3 \% \mathrm{v} / \mathrm{v}$ hydrogen peroxide, blocked for $30 \mathrm{~min}$ in 5\% BSA (w/v), and incubated at $4^{\circ} \mathrm{C}$ with goat anti-RelA (1:100) or mouse anti-Ki67 (1:50; BD Pharmingen). Next, the sections were incubated with biotinylated secondary antibodies and $\mathrm{ABC}$ complex, using DAB as a chromogen (Sigma-Aldrich). Controls were performed by applying the same protocol, but omitting primary antibodies. Samples from four animals of each experimental condition were photographed at 40x, with more than 1000-immunoreactive cells being examined. The Ki67 index was determined using NIH Image J Software (National Institutes of Health), and the number of positively stained nuclei was recorded along with the total nuclei.

\section{Cytochemical detection of SA- $\beta$-Gal staining and double SA- $\beta$-Gal/RelA immunolabelling}

SA- $\beta$-gal-positive cells were detected by using the $\beta$-Gal staining kit (Senescence Cell Staining Kit, Sigma-Aldrich), as previously described (Sabatino et al. 2015). Sections were photographed at $100 x$, with only senescent cells being stained in blue at a $\mathrm{pH}=6.0$. After performing the SA- $\beta$-Gal staining, the same cryosection was processed by immunocytochemistry for the purpose of determining the SA- $\beta$-Gal/RelA double localization, by applying the antiRelA antibody as described in the previous section. Slides with samples from four animals of each experimental condition were photographed in randomly chosen fields at 400x, with more than 1000-immunoreactive cells being examined.

\section{Gene expression analysis by qPCR}

Total RNA was purified using the Direct-zol RNA miniprep kit (Zymo Research, Irvine, CA, USA) according to manufacturer's instruction. Thereafter, $2 \mu \mathrm{g}$ of total RNA from each condition were reverse transcribed using Reverse Transcriptase M-MLV (Promega) with random hexamer primers (Thermo Fisher Scientific). Real-time PCR was used to evaluate the quantitative expression of mRNA for Bcl-2, Bcl- $x l, T N F \alpha, I L-1 \beta$, and HPRT as the control. The cDNA was analysed for control and tumour 
Table 1 Primer sequences for gene expression.

\begin{tabular}{|c|c|c|}
\hline Gene & Accession number & Note \\
\hline$B C l-x l$ & NM 001033672.1 & Gene expression \\
\hline $\mathrm{BCl}-2$ & L14680 & Gene expression \\
\hline$T N F \alpha$ & NM 012675.3 & Gene expression \\
\hline$I L-1 \beta$ & NM 031512 & Gene expression \\
\hline HPRT & NM012583.2 & Gene expression \\
\hline
\end{tabular}

\begin{tabular}{llc}
\hline Sequence & & Amplicom (bp) \\
\cline { 1 - 1 } (F) 5'GCTGGTGGTTGACTTTCTCTCC 3' & 46 \\
(R) 5'GGCTTCAGTCCTGTTCTCTTCG 3' & & \\
(F) 5'ATCGCTCTGTGGATGACTGAGTAC 3' & & 86 \\
(R) 5'AGAGACAGCCAGGAGAAATCAAAC 3' & & \\
(F) 5'AGCACGGAAGCATGATCCG 3' & & 78 \\
(R) 5'CGAGCAGGAATGAGAAGAGG 3' & & \\
(F) 5'GACAAGAGCTTCAGGAAGGC 3' & & \\
(R) 5'GCAAGACATAGGTAGCTGCC 3' & & \\
(F) 5'CTCGAAGTGTTGGATACAGGC 3' & \\
(R) 5' CTTGGCTTTTCCACTTTCGC 3' & \\
\hline
\end{tabular}

conditions using real-time PCR SYBR Green Master Mix (Thermo Fisher Scientific) single stranded cDNA (100 ng of the input total RNA equivalent), and $800 \mathrm{nM}$ of amplification primer were used in a reaction volume of $15 \mu \mathrm{L}$. Runs were performed on a standard 7500 system (Applied Biosystems), and the running condition was $95^{\circ} \mathrm{C}$ for $10 \mathrm{~min}, 40$ cycles at $95^{\circ} \mathrm{C}$ for $15 \mathrm{~s}$, and $60^{\circ} \mathrm{C}$ for $1 \mathrm{~min}$. Gene expression was normalized to the housekeeping gene (HPRT) and calculated using the comparative $2^{-\Delta \Delta \mathrm{Ct}}$ method. Melting curve analyses were performed to ensure the specificity of the qPCR product. These assays were performed four times in duplicate. All primers were from Thermo Fisher and the gene-specific primer sets are described in Table 1.

\section{Statistical analysis}

The statistical analysis was carried out using the Statistica 7.1 program (Statsoft, Tulsa, OK, USA). Data were analysed using a one-way ANOVA, and the main significant effects indicated by the ANOVA were further analysed through Fisher's least significant difference post hoc test.

\section{Results}

\section{NF-kB signalling is activated during the experimental pituitary tumour development.}

In order to analyse the molecular link between NF- $\mathrm{kB}$ activation and pituitary senescence, the cytoplasmic and nuclear RelA protein content and SA- $\beta$-Gal activity were assessed during the tumour development. As shown in Fig. 1A and I, a marked increase in the RelA protein level was detected in the cytosolic compartment, starting from the earliest stages of tumour induction. In addition, a significant NF- $\mathrm{BB}$ activation, as revealed by its increase in the nuclear compartment, was observed mainly after 20 and 40 days of tumour development (Fig. 1B and $\mathrm{H}$ ), thereby demonstrating NF-kB nuclear translocation. Furthermore, an increase in the p-RelA S536 protein levels was detected over tumour development, with a marked enhancement occurring at the E40 endpoint (Fig. 1C and I), thus revealing that NF- $\mathrm{\kappa B}$ is transcriptionally active under this tumoral context. In line with this, immunohistochemistry analysis revealed a marked RelA nuclear localization in the majority of pituitary cells derived from E20 and E40 conditions. Furthermore, the double SA- $\beta-G a l$ and RelA staining in the same cryosection revealed the co-existence of senescent regions with nuclear translocation of NF- $\mathrm{kB}$ for the tumour conditions examined (Fig. 1J). Therefore, with the aim of investigating the induction of the NF- $\mathrm{kB}$ canonical pathway, we evaluated IKK $\alpha / \beta$ phosphorylation (p-IKK $\alpha$ S176/ $\beta$ S180) and the IкB $\alpha$ protein levels during the pituitary tumour development. Figure $1 \mathrm{I}$, shows a representative image of the $\mathrm{p}$-IKK $\alpha$ S176/ $\beta$ S180 protein level detected in the cytosolic compartment after 20 days of tumour induction, concurring with earliest signs of NF- $\kappa B$ activation. Increasing I $\kappa \mathrm{B} \alpha$ protein levels were also observed, starting at E20 and continuing up to the advanced stage of tumour growth (Fig. 1D and I). In addition, in order to evaluate the contribution of p53 and $\mathrm{p}-\gamma \mathrm{H} 2 \mathrm{AX}$ in senescence and NF- $\mathrm{BB}$ activation, their protein levels were determined at different points of the pituitary tumour progression. As shown in Fig. 1E and I, an increase in p53 protein levels was detected from E20 in the cytosolic compartment of pituitary cells. Moreover, although an initial increase in nuclear p53 expression was observed at the E10 endpoint, this signal was no longer observed from E20 (Fig. 1F and H). In parallel, p- $\gamma \mathrm{H} 2 \mathrm{AX}$ expression revealed a gradual increase from the start of tumoral development, but this recovered to normal levels at E60 (Fig. 1G and H). https://joe.bioscientifica.com https://doi.org/10.1530/JOE-19-0506
(C) 2020 Society for Endocrinology Published by Bioscientifica Ltd. Printed in Great Britain 


\begin{tabular}{l|l|l|r|r|}
$\begin{array}{l}\text { Journal of } \\
\text { Endocrinology }\end{array}$ & B Mongi-Bragato et al. & $\begin{array}{l}\text { NF-kB in senescence of } \\
\text { pituitary tumours }\end{array}$ & $\mathbf{2 4 5 : 2}$ & $\mathbf{1 8 3}$ \\
\hline
\end{tabular}

A

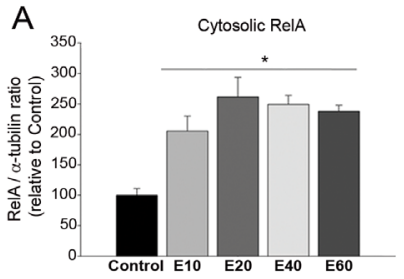

D
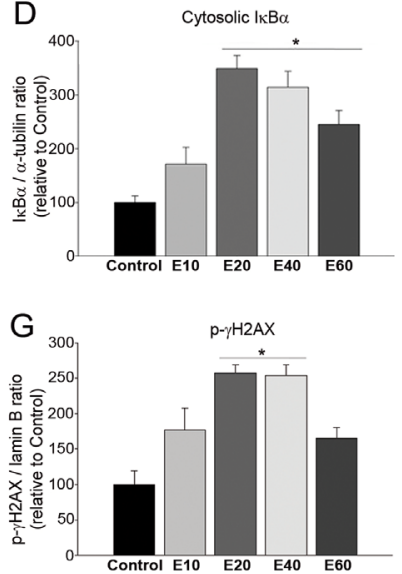

$\mathrm{J}$

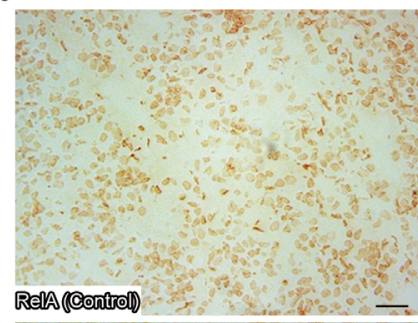

B

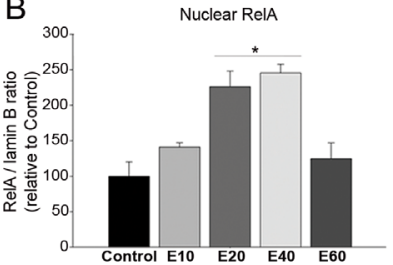

$\mathrm{E}$

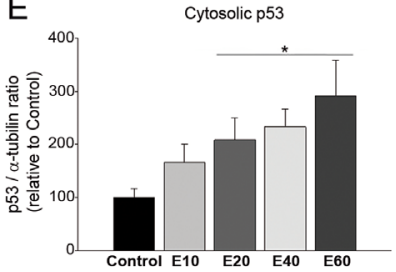

H Nuclear Compartment

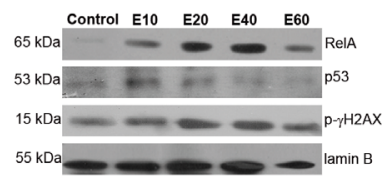

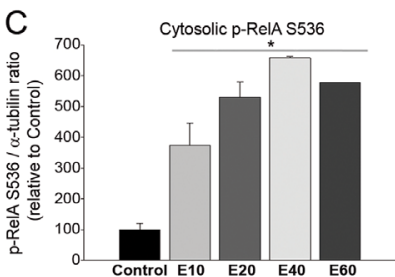

$\mathrm{F}$

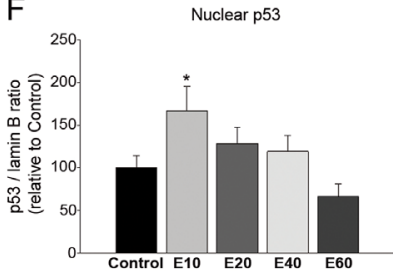

I Cytosolic Compartment

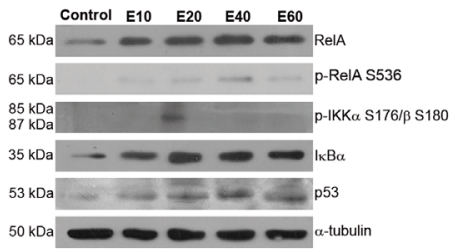

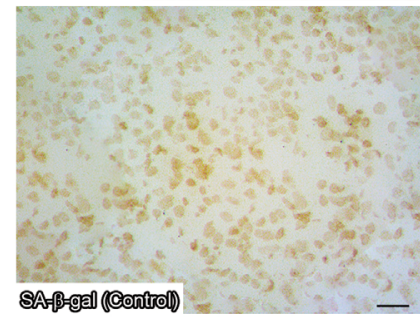
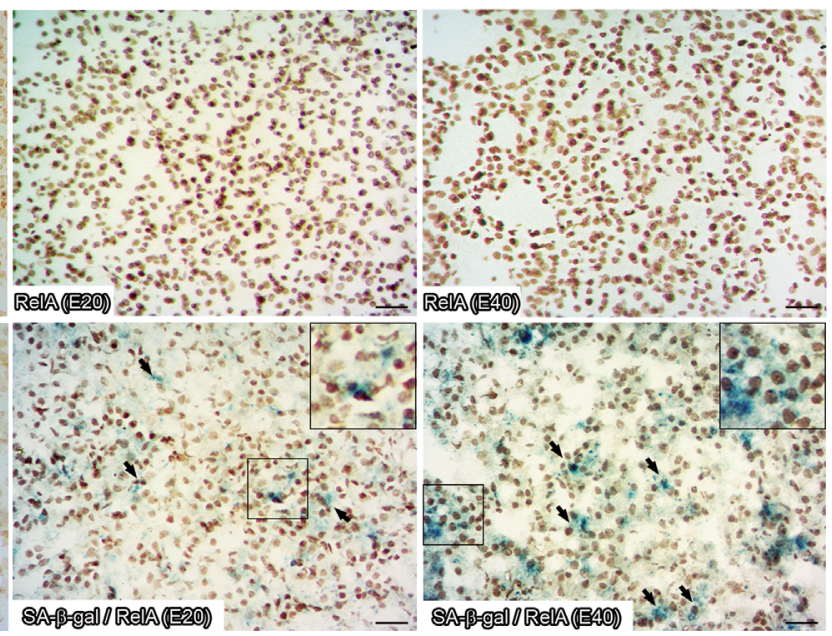

\section{Figure 1}

NF-kB activation during the pituitary tumour development. Densitometric analysis of (A) cytosolic RelA, (B) nuclear RelA, (C) cytosolyc p-RelA S536, (D) cytosolic $1 \kappa B \alpha,(E)$ cytosolic p53, (F) nuclear p53, and (G) $p-\gamma-\mathrm{H} 2 \mathrm{AX}$ protein expression levels during the development of pituitary tumours. The RelA/ $\alpha$-tubulin, p-RelA S536/ $\alpha$-tubulin, IкB $\alpha / \alpha$-tubulin, p53/ $\alpha$-tubulin ratios and RelA/lamin B, p53/lamin B, and p- $\gamma \mathrm{H} 2 \mathrm{AX} / \mathrm{lamin} \mathrm{B}$ ratios are represented as a percentage relative to the control (control data were set to 100\%). (H) Representative Western blot analysis of RelA, p53, and p- $\gamma \mathrm{H} 2 \mathrm{AX}$ nuclear protein levels at the different stages of tumour induction. (I) Representative Western blot analysis of RelA, p-RelA S536, p-IKK $\alpha$ S176/ $\beta$ S180, IkB $\alpha$, and p53 cytosolic protein levels during the development of pituitary tumours. Lamin B and $\alpha$-tubulin signals were used to confirm equivalent total nuclear and cytosolic protein loading, respectively. The data from five independent experiments were evaluated by the ANOVA-Fisher test and expressed as mean \pm S.E. normalised to the control group. $* P<0.05$ vs control. (J) RelA and SA- $\beta$-Gal staining in cryosections from normal and estrogen-induced pituitary tumours. Immunohistochemistry was performed using the Avidin-Biotin peroxidase method (brown signal for RelA) and an enzymatic assay (SA- $\beta$-Gal enzymatic activity dyed blue). The RelA-positive nuclei staining can be seen in the areas labelled for SA- $\beta$-gal in the pituitary parenchyma (inset). However, single cells expressing SA- $\beta$-Gal or RelA can also be discriminated (arrows). Representative fields of anterior pituitary sections of a representative experiment from a total of three independent experiments with similar results are shown. Scale bar: $20 \mu \mathrm{m}$. A full colour version of this figure is available at https://doi.org/10.1530/JOE-19-0506. 


\section{ERK1/2 and Akt activation are suppressed} concomitantly with increased P38 MAPK and JNK phosphorylation in the course of pituitary tumour development

It is known that NF- $\mathrm{kB}$ is an important target for Rasactivated effectors, including ERK1/2 and Akt proteins, with Ras being linked with NF- $\mathrm{kB}$ activation and the expression of certain pro-inflammatory cytokines in senescent cells (Courtois-Cox et al. 2006). In this context, and to elucidate the signalling pathways involved in pituitary tumour growth and the possible crosstalk with NF- $\mathrm{kB}$ activation, we next analysed the ERK1/2 and Akt protein levels. Figure $2 \mathrm{~A}$ and $\mathrm{E}$ show a significant increase in p-ERK1/2 at E10 followed by a marked suppression of this signal at the prolonged stages of tumour induction. Figure $2 \mathrm{~B}$ and $\mathrm{E}$ show a different phosphorylation profile
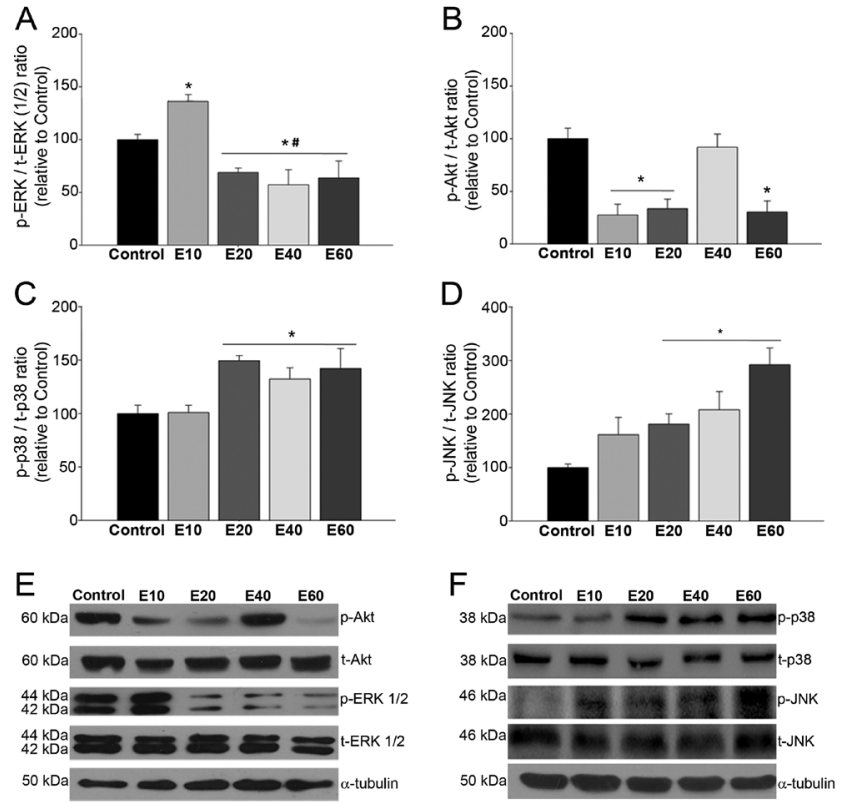

Figure 2

MAPKs and Akt signalling activation during pituitary tumour development. (A) Western blotting expression levels of p-ERK1/2 from cytosolic extracts of normal and tumour pituitaries. An early p-ERK activation was detected at E10, followed by its suppression in the latter stages of tumour development. (B) Western blotting expression levels of p-Akt during tumour progression. (C) Graph panel showing p-p38 protein levels in control and tumour pituitaries. An increase in p-p38 levels was detected from the E20 stage of tumour development. (D) p-JNK protein levels during pituitary tumour development. A progressive increase in p-JNK expression was observed throughout pituitary tumour progression, with a marked rise detected at $\mathrm{E} 60(\mathrm{E})$, and $(\mathrm{F})$ representative images of Western blot showing p-ERK, p-Akt, p-p38, and p-JNK signals are presented. Expression of $\alpha$-tubulin was used as the loading control and confirmed that equal loading occurred in all lines. Data from five independent experiments were evaluated by the ANOVA-Fisher test and represent the mean \pm S.E. normalised to the control group. ${ }^{*} P<0.05$ vs control; $\# P<0.05$ vs E10.

(c) 2020 Society for Endocrinology Published by Bioscientifica Ltd. Printed in Great Britain for Akt. The phosphorylation of this protein was inhibited at all stages of the treatment, except at E40 where it remained at levels similar to those observed at baseline conditions.

The involvement of JNK and p38 MAPK signalling pathways in controlling NF- $\mathrm{kB}$ activation in the senescence programme has also been previously demonstrated (Freund et al. 2011, Schramek et al. 2011). To try to further characterise the NF- $\mathrm{kB}$ activation mechanisms involved in pituitary tumour cell growth, the p-p38 MAPK and p-JNK protein content was examined. Figure $2 \mathrm{C}$ and $\mathrm{F}$ show a significant increase in p-p38 starting at the E20 stage, which strengthened over time until 60 days of tumour development. Additionally, a time-dependent increased p-JNK ratio was revealed, starting from E10 and with a marked enhancement occurring at E60 (Fig. 2D and F).

\section{SASP and pro-survival NF- $\mathrm{kB}$ target gene expression is activated during the development of pituitary tumours}

The balance between cell proliferation and senescence mechanisms, which is linked to NF-kB activation, finally defines the tumour growth. Having demonstrated that NF-kB activation in senescent cells (Fig. 1E) is also accompanied by p38 MAPK activation (Fig. 2C and F), we examined the transcriptional role of different NF-кB-target genes implicated in the SASP phenotype. A significantly increased TNF $\alpha$ expression was detected at the E20 and E40 stages, which returned to the basal level by the end of tumour induction (Fig. 3A). Interestingly, a remarkable enhancement of the IL1 $\beta$ expression levels was observed at stages E40 and E60 (Fig. 3B).

In order to explore NF-kB-regulated pro-survival gene expression, the $B c l-2$ and $B c l-x l$ gene expression was assessed. Figure $3 \mathrm{C}$ shows increased $\mathrm{Bcl}-2$ expression at the beginning of tumour development (E10 and E20), with these values gradually returning to the basal condition. However, in the case of $B c l-x l$, its expression was not induced until the E20 and E40 stages of tumour induction (Fig. 3D).

\section{NF-кB inhibition attenuated the emergence of cellular senescence in pituitary tumours}

It has been demonstrated that NF-kB genetic or pharmacological inhibition abrogates cellular senescence by reducing growth arrest and SASP expression (Tilstra et al. 2012, Moiseeva et al. 2013). Considering the substantial NF- $\mathrm{kB}$ activation observed at the specific 

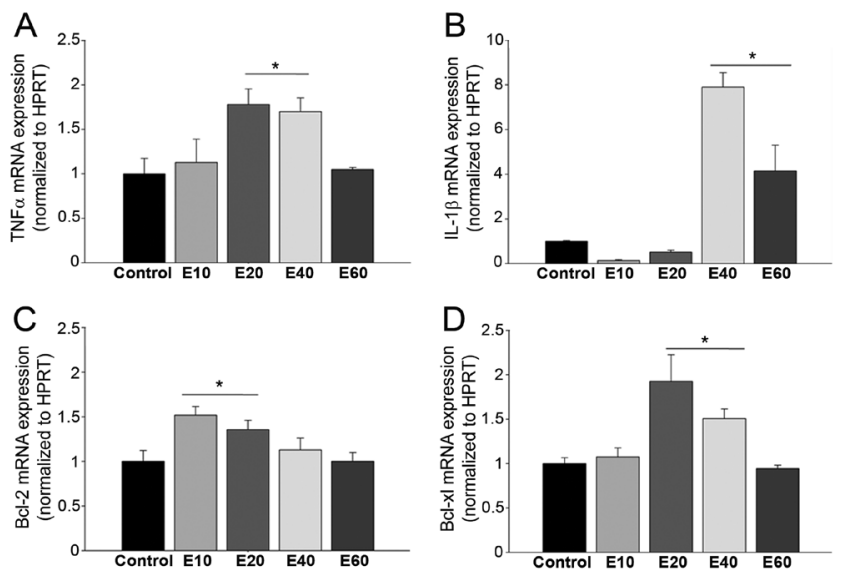

Figure 3

SASP and pro-survival NF- $\mathrm{B}$ target gene expression during pituitary tumour progression. (A) TNF $\alpha$ and (B) IL-1 $\beta$ gene expression levels in normal and tumour pituitaries. The significant increase in both NF-kBcontrolled cytokines detected at the advanced stages of tumour induction indicates NF-kB control on the transcriptional programme mediating cellular senescence. (C) Bcl-2 mRNA expression levels were augmented at the initial steps of tumour development (E10 and E20), returning progressively to basal levels as the tumour developed. (D) $\mathrm{Bcl}-\mathrm{xl}$ gene expression levels during pituitary tumour development. HPRT was amplified as a housekeeping gene and showed no changes during the experiments. Data were evaluated by the ANOVA-Fisher test and are expressed as mean \pm S.E. of tumour/control pituitary ratio $(n=4$ per group). ${ }^{\star} P<0.05$ vs control.

end-points of pituitary tumour development (Fig. 1A and B), and also the up-regulation of the NF-kB-downstream target genes associated with the senescence secretome and proliferation control at the same stages of tumour induction (Fig. 3), the next step taken was to try to corroborate these findings under in vivo NF-kB inhibition. Since simultaneous NF-кB nuclear translocation and IKK activation were detected at E20, NF- $\mathrm{BB}$ signalling was then pharmacologically inhibited by daily PDTC administration for 20 days (PDTC-E20 group). PDTC treatment did not induce any changes in body weight, food, water intake, or behaviour (data not shown). Figure $4 \mathrm{~A}$ shows that, as expected, PDTC administration inhibited NF-kB nuclear translocation after 20 days of pituitary lesion progression.

Figure 4B reveals that the pharmacological NF-кB blockage slightly, but significantly, reduced the pituitary tumour weight at PDTC-E20 when compared to the E20 endpoint, with macroscopic observation in sellae of the pituitaries for the different experimental conditions also confirming this weight reduction (Fig. 4C). To determine the effect of NF-kB inhibition on cellular senescence, the SA- $\beta$-Gal enzymatic activity and cell proliferation were also measured under PDTC treatment. As shown in Fig. $4 \mathrm{D}$ and $\mathrm{E}, \mathrm{PDCT}$ was able to reduce SA- $\beta-\mathrm{Gal}$ reactivity at the E20 stage of tumour development. In addition, the quantification of Ki67-immunopositive cells revealed a significant decrease of cellular growth in animals receiving the PDTC inhibitor compared to the E20 group (Fig. 4F and G).

\section{Discussion}

In the present study, we have demonstrated the significant role exerted by NF-кB on the pituitary cellular senescence process during the development of in vivo experimental tumours. Moreover, our findings have delineated the possible signalling pathways involved in the control of NF-KB activation, which includes the induction of specific SASP-related NF-kB target genes. We have also shown the attenuation of SA- $\beta$-Gal expression through an in vivo NF-kB inhibition approach. In addition to its contribution in the pituitary cell growth control via senescence, NF-кB also stimulated pituitary cell proliferation, with this finding being correlated by up-regulation of relevant pro-survival NF- $\mathrm{kB}$ target genes, thus demonstrating the coexistence of both cellular processes during the development of pituitary tumours.

Senescence has been proposed as a defence mechanism underlying the failure of benign pituitary tumours to progress to true malignancy (Chesnokova et al. 2008, Melmed 2015). Regarding this, human tumours with high levels of SA- $\beta-$ Gal activity express elevated p21 levels, but, this cyclin-dependent kinase inhibitor was not detected in human pituitary carcinomas (Chesnokova et al. 2008). Accordingly, several in vivo studies have demonstrated that senescence is indeed a contributing factor to the benign nature of pituitary tumours (Donangelo et al. 2006, Chesnokova et al. 2008). In line, we have previously demonstrated clear hallmarks of cellular senescence as a potent tumour suppressor process in experimental pituitary tumours, indicating a role for this mechanism in the regulation of pituitary cell growth (Sabatino et al. 2015).

Nevertheless, the factors and molecular mechanisms behind the capability of the pituitary gland to avoid unregulated cell proliferation and exactly how the cellular signalling networks are integrated are still not well understood. One targeted candidate is the NF- $\mathrm{BB}$ transcription factor, with there being evidence indicating that this transcription factor is substantially increased in the cytoplasm and nucleus in human pituitary adenomas (Chen et al. 2015). In agreement, by using experimental estrogen-induced pituitary tumours that constituted a faithful in vivo model of senescence, we demonstrated 

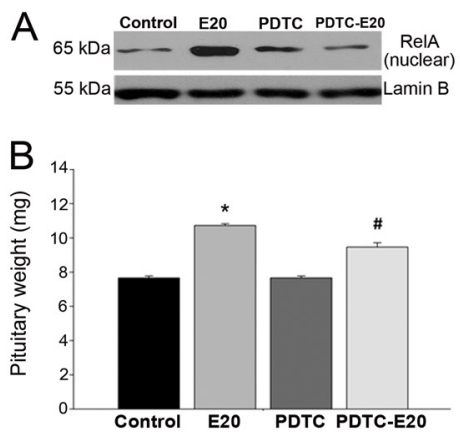

C

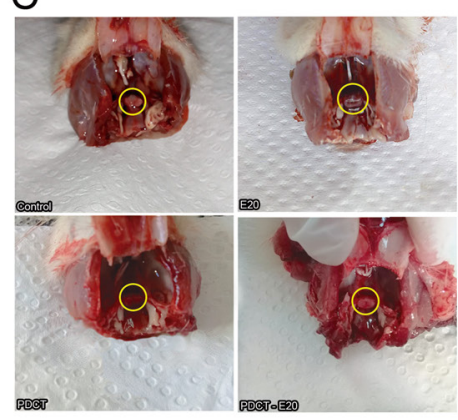

D
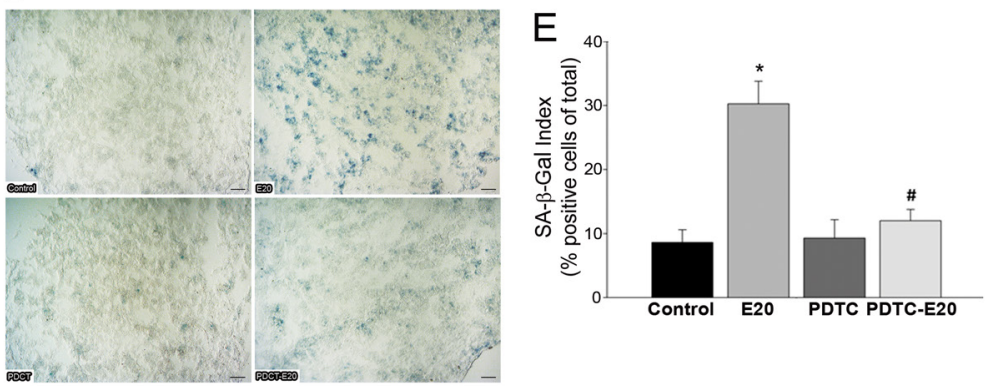

F

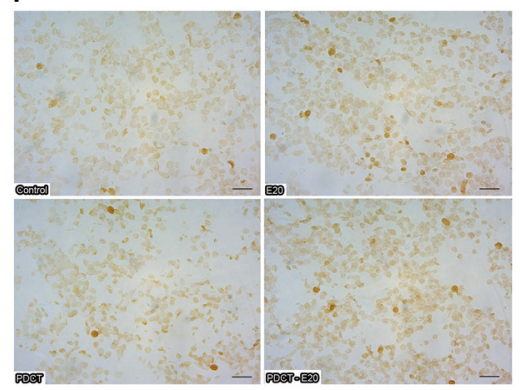

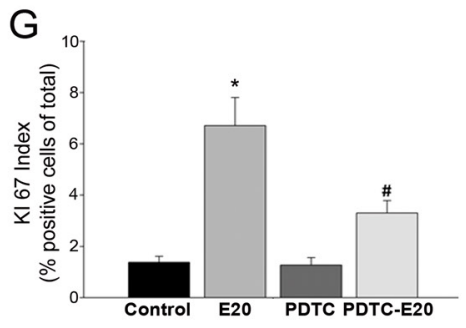

Figure 4

$\mathrm{NF}-\mathrm{kB}$ inhibition attenuates the emergence of the cellular senescence and proliferation processes during in vivo pituitary tumour development. (A) Representative Western blot analysis of RelA nuclear protein expression. PDTC treatment ( $50 \mathrm{mg} / \mathrm{kg}$, i.p.; 20 days) was able to block NF-kB nuclear translocation in in vivo estrogen-induced tumours. Expression of lamin B confirmed equal loading occurring in all lanes. (B) Pituitary weight (mg) after estrogen and/or PDTC ( $50 \mathrm{mg} / \mathrm{kg}$ ) administered daily for 20 days. The data were evaluated by the ANOVA-Fisher test and are expressed as mean \pm s.E. ( $n=5$ per group). ${ }^{*} P<0.05$ vs control $\# P<0.05$ vs E20. (C) Photographs of representative in sellae pituitaries from normal ones and those submitted to 20 days of tumour development, with or without PDTC treatment (50 mg/kg/i.p.). Pituitary gland sizes are depicted by a circle. (D) Pituitary cryosections stained with SA- $\beta$-Gal (blue signal) from control and E20 tumour glands from animals treated with vehicle or PDTC. Scale bar: $60 \mu \mathrm{m}$. Pituitary tumour from animals treated with the NF-kB inhibitor PDTC showed a reduced SA- $\beta$-gal reactivity at E20 compared to E20 without PDTC. (E) The SA- $\beta$-gal index from the different experimental conditions. (F) Ki67 immunolabelling (brown signal) in cryosections of normal glands and E20 pituitary tumours from animals treated with PDTC or vehicle. A reduction in Ki67 immunoreactivity was seen after daily PDTC injection for 20 days of evolution of proliferative injury. Scale bar: $20 \mu \mathrm{m}$. (G) Ki67 index for the different experimental conditions. Data were statistically analysed by the ANOVA-Fisher's test, and the results are expressed mean \pm s.E. ( $n=4$ per group). ${ }^{*} P<0.05 \mathrm{vs}$ control $\# P<0.05 \mathrm{vs} \mathrm{E20} \mathrm{group.} \mathrm{A} \mathrm{full} \mathrm{colour} \mathrm{version} \mathrm{of} \mathrm{this} \mathrm{figure} \mathrm{is} \mathrm{available} \mathrm{at} \mathrm{https://doi.}$ org/10.1530/JOE-19-0506.

an increase in cytosolic NF- $\mathrm{B}$ levels during pituitary tumour development, accompanied by NF- $\mathrm{B}$ nuclear translocation at the specific endpoints E20 and E40, which may suggest that there exists a limited time period of transcriptional activity by NF- $\mathrm{BB}$ over the course of tumour progression.

The NF-кB canonical pathway activation classically involves phosphorylation and proteasomal-mediated degradation of the inhibitory protein $\mathrm{I} \kappa \mathrm{B} \alpha$. Interestingly, increased $\mathrm{I} \kappa \mathrm{B} \alpha$ protein levels were found as the pituitary tumour advanced, with the first sign of an $\mathrm{I} \kappa \mathrm{B} \alpha$ increase being detected at the tumour stages where NF- $\mathrm{B}$ nuclear translocation was observed. Regarding this, several authors have pointed out that NF-кB stimuli appear to trigger negative feedback pathways in some cell types, such as the hepatoma cell line and human colon cell line, which terminate the NF- $\mathrm{BB}$ response by increasing the stability of newly synthesized $\mathrm{I} \kappa \mathrm{B} \alpha$ (Place et al. 2001, 2003,
Werner et al. 2005, 2008, Moss et al. 2012) Thus, the rise in $\mathrm{I} \kappa \mathrm{B} \alpha$ protein levels detected followed by NF- $\kappa \mathrm{B}$ nuclear translocation may suggest that a regulatory mechanism was triggered in order to modulate NF- $\kappa \mathrm{B}$ activation in experimental pituitary tumours. Thus, in this context, the absence of NF- $\mathrm{B}$ nuclear translocation at E60 stage could be a result of the negative feedback from I $\mathrm{B} \alpha$.

The activity of NF- $\kappa \mathrm{B}$ is also regulated by a plethora of pathways, whose activation depends on the cellular context. The PI3K/Akt and MEK/ERK signalling are critical for inducing the cellular senescence phenotype (Satyanarayana et al. 2004, Kim et al. 2017), with both these pathways being associated with IKK/NF-кB complex activation in a tumour context (Tyagi et al. 2014). Despite these findings, the $\mathrm{p}-\mathrm{IKK} / \mathrm{NF}-\kappa \mathrm{B}$ nuclear accumulation detected at the E20 and E40 stages appeared to be ERK and Akt-independent, since both pathways were mainly suppressed during pituitary tumour development. 
Regarding Akt signalling, the reestablishment of p-Akt to control levels at E40 stage might be a response to extracellular events occurring within the tumour setting (Sabatino et al. 2018). Moreover, the ERK activation detected at the earlier stages of tumour induction was correlated with the initial burst of proliferation, which was followed by cellular senescence (Sabatino et al. 2015). Furthermore, these results are consistent with previous evidence showing that, after a transient activation of downstream Ras effectors, there was a shutdown of this signalling as a negative feedback underlying cellular senescence (Courtois-Cox et al. 2006, Hayes et al. 2016).

The involvement of additional signalling pathways that control NF-kB and the senescence programme has also been demonstrated (Freund et al. 2011). This mechanism can be triggered by the JNK signalling activation through p53 regulation (Schramek et al. 2011), and an intrinsic crosstalk between NF-kB and JNK has been reported (Bubici et al. 2004). Furthermore, p38 MAPK regulates SASP mainly through NF-кB transcriptional activity, which is required for the expression of most SASP factors (Salminen et al. 2012). Supporting these evidences, under the present experimental conditions, we detected sustained p38 MAPK and JNK activation from E20 stage, which corresponded with IKK phosphorylation and NF-kB nuclear translocation at the same endpoint of tumour induction. Moreover, the SASP components evaluated in our study were detected concomitantly with p38 MAPK/NF-kB induction, possibly indicating that this pathway is linked to the senescence secretome expression during pituitary tumour progression.

It has been reported that the p38 MAPK/NF-кB pathway is a necessary and sufficient DNA damage response (DDR)-independent regulator of the senescence secretome (Freund et al. 2011). Nevertheless, DDR could also be triggered and orchestrated in cooperation with NF- $\mathrm{kB}$, the senescence machinery in pituitary tumours (Sabatino et al. 2015). Interestingly, we found increased p53 activation occurring only at the early stages of tumour development and with $\mathrm{p}-\gamma \mathrm{H} 2 \mathrm{AX}$ induction starting at E20, as previously reported in our laboratory (Sabatino et al. 2015, 2018). The cytoplasmic p53 retention observed from E20 might indicate its incapability to exert its canonical functions, so it is possible that p53 is able to initiate senescence arrest. Interestingly, NF-kB activation was detected after the reduction in p53 nuclear levels. In agreement, it has been previously described that NF- $\mathrm{kB}$ and p53 engage in reciprocal negative regulation (Huang et al. 2007, Xia et al. 2009). Thus, it is possible that NF- $\mathrm{kB}$ takes control of cellular senescence machinery after the E20 endpoint in a p53-independent fashion.
In order to address a possible relationship between NF- $\mathrm{kB}$ activation and pituitary senescence, we first analysed the joint expression of this transcription factor and SA- $\beta-G a l$. A co-expression of SA- $\beta-G a l$ and RelA was detected at the E20 stage of tumour growth, revealing NF-kB activation upon pituitary senescence. Also, in vivo exposition to the NF-kB inhibitor PDTC dramatically suppressed the emergence of cellular senescence at the E20 endpoint, as evidenced by reduction in SA- $\beta$-Gal activity.

Although several in vitro studies have demonstrated the preponderant role exerted by NF- $\mathrm{KB}$ on cellular senescence and its influence in tumour initiation and progression (Coppe et al. 2010, Rovillain et al. 2011), few studies have extended these observations to the in vivo model, while other studies have produced some conflicting results. For example, NF- $\mathrm{BB}$ activation was reported to promote senescence and SASP induction together with suppressed proliferation (Liu et al. 2012, Xu et al. 2018), whereas in other investigations, its blockade promoted senescence and replicative arrest of tumour cells (Nogueira et al. 2011). Thus, the putative dual role of $\mathrm{NF}-\mathrm{kB}$ in tumour promotion or suppression may depend on the biological setting in which this transcription factor is activated. Accordingly, during pituitary tumour development, NF- $\mathrm{kB}$ appears to be implicated in both senescence and proliferative responses. This notion is supported by the enhancement detected in mRNA levels of several pro-survival factors, such as $B c l-2$ and $B c l-x l$ (transcriptionally controlled by NF-kB), at those stages of tumour development where this transcription factor was mainly detected in the nuclear compartment. Moreover, at the same time, the $T N F \alpha$ and $I L-1 \beta$ mRNA levels were also increased.

If the senescence phenomenon emerges with the aim to counteract the exacerbated tumour growth by activating the immune response (Acosta et al. 2008, Coppe et al. 2008, Rovillain et al. 2011), the proliferation would be expected to be increased when senescence is inhibited. Nevertheless, several investigations have suggested that SASP from senescent cells can also act extrinsically and promote cell transformation (Coppe et al. 2010, Franceschi \& Campisi 2014). Moreover, persistent SASP may help tumour cells to migrate and invade (Coppe et al. 2008, Tammela et al. 2017). It was also demonstrated that endogenous IL-6, as a SASP component, and hormone secretion (Chesnokova et al. 2013, Sapochnik et al. 2017) underlie the senescence-associated slow proliferation rate and benign nature of pituitary tumours. In contrast, other evidence indicates that senescence and pituitary stem cell associated persistent activation of SASP drive paracrine 
tumour formation (Mertens et al. 2015, Carreno et al. 2017, Gonzalez-Meljem et al. 2017, Gonzalez-Meljem \& Martinez-Barbera 2018). Thus, our observations showing that, when NF-kB activation was inhibited, cell senescence was prevented with cell proliferation being only slightly suppressed could be explained by the differential contribution of senescence in benign pituitary tumour evolution. Moreover, given the preponderant role of NF- $\mathrm{kB}$ in proliferation and tumour cell growth (Xia et al. 2014), the inhibition of this transcription factor in the context of pituitary tumour may induce a slight reduction in the proliferation.

Although the progression from a benign to an aggressive/malignant character is still a matter of controversy, it possibly results as a consequence of bypassed senescence (Chesnokova et al. 2008, Melmed 2011). Furthermore, multiple molecular events may occur to initiate the transformation from benign pituitary adenomas to aggressive and/or malignant ones, including cell cycle gene dysregulation, epigenetic modifications, oncogene activation, and tumour suppressor gene inactivation (Melmed 2011), with some factors also being involved in senescence growth arrest. Also, in the tumour microenvironment, SASP paracrine components such as VEGF (Lloyd et al. 1999, Ortiz et al. 2012) and matrix metalloproteinase 9 (Turner et al. 2000) possibly contribute to the transformation of pituitary adenomas to carcinomas, but the exact mechanism still remains unclear. Moreover, the transformation to pituitary carcinomas might be cell-type specific, mainly occurring in PRL- and ACTH-secreting tumours, possibly because these adenomas are less likely to show markers of senescence, when compared with other adenoma types (Alexandraki et al. 2012). In line, it has been hypothesized that disruption of the pituitary tumour transforming gene (PTTG) and p21 pathways that induce cell senescence and thus prevent malignant transformation is involved in the transition of adenomas into carcinomas (Chesnokova et al. 2008). In spite of evidence indicating a correlation of senescence secretome components with a transition to pituitary malignancy, a great body of literature shows that senescence is implicated in the benign nature of these lesions, thereby increasing the capability of the pituitary gland to avoid unregulated cell proliferation

The fact that, during the early stages of pituitary tumour development, the proliferation was not completely suppressed, with the senescence being substantially reduced after NF-кB blockade, may support the hypothesis of a competition occurring between these crucial processes (cell senescence and proliferation) with a

\section{Pituitary Tumour Cell Microenviroment}

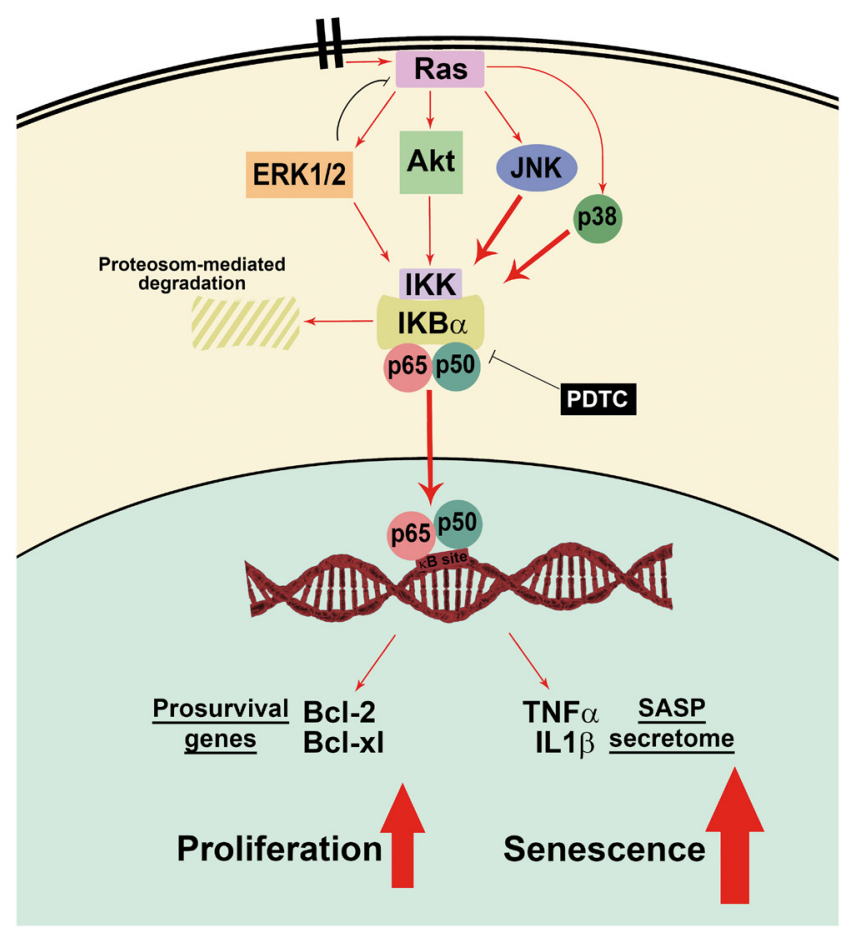

Figure 5

Model for signalling pathways involved in NF-кB activation during the development of experimental pituitary tumours. NF-кB regulates TNF $\alpha$ and IL $1-\beta$ as specific SASP-related NF-kB target genes as well as BCl-2 and $\mathrm{Bcl}-\mathrm{xl}$ as pro-survival genes at specific stages of tumour progression. Pharmacological NF-kB blockage (PDTC administration) induced a marked reduction in SA- $\beta$-Gal activity and a slight decrease in Ki67 immunopositive cells, thus exposing the pivotal role of NF-kB in the regulation of pituitary cell growth. A full colour version of this figure is available at https://doi.org/10.1530/JOE-19-0506.

differential contribution of NF-kB in order to control the pituitary neoplastic growth (Fig. 5). In line, the double SA- $\beta$-Gal-/Ki67 positive cells revealed a non-overlapping distribution of pituitary cells (Sabatino et al. 2015), which allowed us to reveal differential role of senescence and proliferation in the temporal course of the development of proliferative lesions. These findings demonstrate a key role of NF-kB in pituitary senescence and also suggest that other NF-кB-independent mechanisms take control of the cell proliferation process at the first stages of tumour induction. Indeed, ROS and certain oxidative stress biomolecules that remain elevated during pituitary tumour development can also lead to sustained pituitary tumour growth (Sabatino et al. 2018).

Collectively, our data may expose the coexistence of different NF- $\mathrm{BB}$ activation pathways that leads to trigger an intricate signalling network tending to suppress mitogenic responses, while at the same time, promoting molecular events that encourage the cellular senescence process. 
Thus, activation of this pivotal transcription factor in pituitary tumours could be considered to be a relevant player that may contribute to the slow and benign characteristics of pituitary neoplastic growth.

Given the key role of senescence as a barrier against tumour progression, a better understanding of the ways in which the underlying molecular targets can control the in vivo senescence may help in the design of novel compounds that can limit tumour cell growth and hormone secretion or even in the development of preventive strategies for tumour treatment.

\section{Declaration of interest}

The authors declare that there is no conflict of interest that could be perceived as prejudicing the impartiality of the research reported.

\section{Funding}

This work was supported by the Fondo Nacional de Ciencia y Tecnología (AGENCIA-FONCyT; Resol. N N 270-15-PICT-2014-1987), Secretaría de Ciencia y Tecnología de la Universidad Nacional de Córdoba (SECyT-UNC Resol. N³13/16; 113/17) and Fundación Florencio Fiorini.

\section{Author contribution statement}

$B$ M B planned and performed the majority of the experiments and wrote the major part of the manuscript. B M B and A D P contributed to study design and planned the experiments. $B M B, L d V S, E G, A C V$, and N S performed the experiments and collected the study data. B M B, A L, R $B$ L, A I T, S G, and A D P contributed to data analysis and interpretation. All the authors contributed to manuscript writing and read and approved the final manuscript. R B L, A I T, S G, and A D P reviewed the manuscript and contributed to quality control. All authors have reviewed the study and approved the final version.

\section{Acknowledgements}

The authors wish to thank Dr Carolina Leimgruber, Dr Virginia Juarez, E E Nestor Boetto, Ms Lucía Artino, and Mr Marcos Almirón for their excellent technical assistance. The authors would also like to thank native speaker Dr Paul Hobson for revising the manuscript.

\section{References}

Acosta JC, O'Loghlen A, Banito A, Guijarro MV, Augert A, Raguz S, Fumagalli M, Da Costa M, Brown C, Popov N, et al. 2008 Chemokine signaling via the CXCR2 receptor reinforces senescence. Cell 133 1006-1018. (https://doi.org/10.1016/j.cell.2008.03.038)

Alexandraki KI, Munayem Khan M, Chahal HS, Dalantaeva NS, Trivellin G, Berney DM, Caron P, Popovic V, Pfeifer M, Jordan S, et al. 2012 Oncogene-induced senescence in pituitary adenomas and carcinomas. Hormones 11 297-307. (https://doi.org/10.14310/ horm.2002.1358)
Asa SL \& Ezzat S 2009 The pathogenesis of pituitary tumors. Annual Review of Pathology 4 97-126. (https://doi.org/10.1146/annurev. pathol.4.110807.092259)

Bubici C, Papa S, Pham CG, Zazzeroni F \& Franzoso G 2004 NF-kappaB and JNK: an intricate affair. Cell Cycle 3 1524-1529. (https://doi. org/10.4161/cc.3.12.1321)

Campisi J \& Robert L 2014 Cell senescence: role in aging and age-related diseases. Interdisciplinary Topics in Gerontology 39 45-61. (https://doi. org/10.1159/000358899)

Carreno G, Gonzalez-Meljem JM, Haston S \& Martinez-Barbera JP 2017 Stem cells and their role in pituitary tumorigenesis. Molecular and Cellular Endocrinology 445 27-34. (https://doi.org/10.1016/j. mce.2016.10.005)

Chen Z, Li Z, Chang Y, Ma L, Xu W, Li M, Li J, Zhang W, Sun Q, An X, et al. 2015 Relationship between NF-kappaB, MMP-9, and MICA expression in pituitary adenomas reveals a new mechanism of pituitary adenomas immune escape. Neuroscience Letters 597 77-83. (https://doi.org/10.1016/j.neulet.2015.04.025)

Chesnokova V, Zonis S, Rubinek T, Yu R, Ben-Shlomo A, Kovacs K, Wawrowsky K \& Melmed S 2007 Senescence mediates pituitary hypoplasia and restrains pituitary tumor growth. Cancer Research $\mathbf{6 7}$ 10564-10572. (https://doi.org/10.1158/0008-5472.CAN-07-0974)

Chesnokova V, Zonis S, Kovacs K, Ben-Shlomo A, Wawrowsky K, Bannykh S \& Melmed S 2008 p21(Cip1) restrains pituitary tumor growth. PNAS 105 17498-17503. (https://doi.org/10.1073/ pnas.0804810105)

Chesnokova V, Zhou C, Anat BS, Svetlana Z, Yuji T, Song-Guang R \& Melmed S 2013 Growth hormone is a cellular senescence target in pituitary and nonpituitary cells. PNAS $1103331-3339$. (https://doi. org/10.1073/pnas.1310589110)

Chien Y, Scuoppo C, Wang X, Fang X, Balgley B, Bolden JE, Premsrirut P, Luo W, Chicas A, Lee CS, et al. 2011 Control of the senescenceassociated secretory phenotype by NF-kappaB promotes senescence and enhances chemosensitivity. Genes and Development 25 2125-2136. (https://doi.org/10.1101/gad.17276711)

Coppe JP, Patil CK, Rodier F, Sun Y, Munoz DP, Goldstein J, Nelson PS, Desprez PY \& Campisi J 2008 Senescence-associated secretory phenotypes reveal cell-nonautonomous functions of oncogenic RAS and the p53 tumor suppressor. PLoS Biology 6 2853-2868. (https://doi. org/10.1371/journal.pbio.0060301)

Coppe JP, Desprez PY, Krtolica A \& Campisi J 2010 The senescenceassociated secretory phenotype: the dark side of tumor suppression. Annual Review of Pathology 5 99-118. (https://doi.org/10.1146/ annurev-pathol-121808-102144)

Courtois-Cox S, Genther Williams SM, Reczek EE, Johnson BW, McGillicuddy LT, Johannessen CM, Hollstein PE, MacCollin M \& Cichowski K 2006 A negative feedback signaling network underlies oncogene-induced senescence. Cancer Cell 10 459-472. (https://doi. org/10.1016/j.ccr.2006.10.003)

Cuzzocrea S, Chatterjee PK, Mazzon E, Dugo L, Serraino I, Britti D, Mazzullo G, Caputi AP \& Thiemermann C 2002 Pyrrolidinedithiocarbamate attenuates the development of acute and chronic inflammation. British Journal of Pharmacology 135 496-510. (https://doi.org/10.1038/sj.bjp.0704463)

Donangelo I, Gutman S, Horvath E, Kovacs K, Wawrowsky K, Mount M \& Melmed S 2006 Pituitary tumor transforming gene overexpression facilitates pituitary tumor development. Endocrinology 147 4781-4791. (https://doi.org/10.1210/en.2006-0544)

Franceschi C \& Campisi J 2014 Chronic inflammation (inflammaging) and its potential contribution to age-associated diseases. Journals of Gerontology: Series A, Biological Sciences and Medical Sciences 69 (Supplement 1) S4-S9. (https://doi.org/10.1093/gerona/glu057)

Freund A, Patil CK \& Campisi J 2011 P38MAPK is a novel DNA damage response-independent regulator of the senescence-associated secretory phenotype. EMBO Journal 30 1536-1548. (https://doi.org/10.1038/ emboj.2011.69) 
Gonzalez-Meljem JM \& Martinez-Barbera JP 2018 Senescence drives noncell autonomous tumorigenesis in the pituitary gland. Molecular and Cellular Oncology 5 e1435180. (https://doi.org/10.1080/23723556.201 8.1435180)

Gonzalez-Meljem JM, Haston S, Carreno G, Apps JR, Pozzi S, Stache C, Kaushal G, Virasami A, Panousopoulos L, Mousavy-Gharavy SN, et al. 2017 Stem cell senescence drives age-attenuated induction of pituitary tumours in mouse models of paediatric craniopharyngioma. Nature Communications 8 1819. (https://doi.org/10.1038/s41467-01701992-5)

Hayes TK, Neel NF, Hu C, Gautam P, Chenard M, Long B, Aziz M, Kassner M, Bryant KL, Pierobon M, et al. 2016 Long-term ERK inhibition in KRAS-mutant pancreatic cancer is associated with MYC degradation and senescence-like growth suppression. Cancer Cell 29 75-89. (https://doi.org/10.1016/j.ccell.2015.11.011)

Hernandez-Segura A, Nehme J \& Demaria M 2018 Hallmarks of cellular senescence. Trends in Cell Biology 28 436-453. (https://doi. org/10.1016/j.tcb.2018.02.001)

Huang WC, Ju TK, Hung MC \& Chen CC 2007 Phosphorylation of CBP by IKKalpha promotes cell growth by switching the binding preference of CBP from p53 to NF-kappaB. Molecular Cell 26 75-87. (https://doi.org/10.1016/j.molcel.2007.02.019)

Karin M 2006 Nuclear factor-kappaB in cancer development and progression. Nature 441 431-436. (https://doi.org/10.1038/ nature04870)

Kim YY, Jee HJ, Um JH, Kim YM, Bae SS \& Yun J 2017 Cooperation between p21 and Akt is required for p53-dependent cellular senescence. Aging Cell 16 1094-1103. (https://doi.org/10.1111/ acel.12639)

Kuilman T \& Peeper DS 2009 Senescence-messaging secretome: SMSing cellular stress. Nature Reviews: Cancer 9 81-94. (https://doi. org/10.1038/nrc2560)

Kuilman T, Michaloglou C, Mooi WJ \& Peeper DS 2010 The essence of senescence. Genes and Development 24 2463-2479. (https://doi. org/10.1101/gad.1971610)

Kwong J, Hong L, Liao R, Deng Q, Han J \& Sun P 2009 p38alpha and p38gamma mediate oncogenic ras-induced senescence through differential mechanisms. Journal of Biological Chemistry 284 11237-11246. (https://doi.org/10.1074/jbc.M808327200)

Lee BY, Han JA, Im JS, Morrone A, Johung K, Goodwin EC, Kleijer WJ, DiMaio D \& Hwang ES 2006 Senescence-associated beta-galactosidase is lysosomal beta-galactosidase. Aging Cell 5 187-195. (https://doi. org/10.1111/j.1474-9726.2006.00199.x)

Liu SF, Ye X \& Malik AB 1999 Inhibition of NF-kappaB activation by pyrrolidinedithiocarbamate prevents in vivo expression of proinflammatory genes. Circulation 100 1330-1337. (https://doi. org/10.1161/01.cir.100.12.1330)

Liu K, Feng T, Liu J, Zhong M \& Zhang S 2012 Silencing of the DEK gene induces apoptosis and senescence in CaSki cervical carcinoma cells via the up-regulation of NF-kappaB p65. Bioscience Reports 32 323-332. (https://doi.org/10.1042/BSR20100141)

Lloyd RV, Scheithauer BW, Kuroki T, Vidal S, Kovacs K \& Stefaneanu L 1999 Vascular endothelial growth factor (VEGF) expression in human pituitary adenomas and carcinomas. Endocrine Pathology 10 229-235. (https://doi.org/10.1007/bf02738884)

Lopez-Otin C, Blasco MA, Partridge L, Serrano M \& Kroemer G 2013 The hallmarks of aging. Cell 153 1194-1217. (https://doi.org/10.1016/j. cell.2013.05.039)

Maiza JC \& Caron P 2009 Pituitary carcinomas and aggressive adenomas: an overview and new therapeutic options. Annales d'Endocrinologie 70 (Supplement 1) S12-S19. (https://doi.org/10.1016/S00034266(09)72471-0)

Melmed S 2011 Pathogenesis of pituitary tumors. Nature Reviews: Endocrinology 7 257-266. (https://doi.org/10.1038/nrendo.2011.40)

Melmed S 2015 Pituitary tumors. Endocrinology and Metabolism Clinics of North America 44 1-9. (https://doi.org/10.1016/j.ecl.2014.11.004)
Mertens F, Gremeaux L, Chen J, Fu Q, Willems C, Roose H, Govaere O, Roskams T, Cristina C, Becú-Villalobos D, et al. 2015 Pituitary tumors contain a side population with tumor stem cell-associated characteristics. Endocrine-Related Cancer 22 481-504. (https://doi. org/10.1530/ERC-14-0546)

Miao C, Lv Y, Zhang W, Chai X, Feng L, Fang Y, Liu X \& Zhang X 2017 Pyrrolidinedithiocarbamate (PDTC) attenuates cancer cachexia by affecting muscle atrophy and fat lipolysis. Frontiers in Pharmacology $\mathbf{8}$ 915. (https://doi.org/10.3389/fphar.2017.00915)

Moiseeva O, Deschenes-Simard X, St-Germain E, Igelmann S, Huot G, Cadar AE, Bourdeau V, Pollak MN \& Ferbeyre G 2013 Metformin inhibits the senescence-associated secretory phenotype by interfering with IKK/NF-kappaB activation. Aging Cell 12 489-498. (https://doi. org/10.1111/acel.12075)

Mongi-Bragato B, Zamponi E, Garcia-Keller C, Assis MA, Virgolini MB, Masco DH, Zimmer A \& Cancela LM 2016 Enkephalin is essential for the molecular and behavioral expression of cocaine sensitization. Addiction Biology 21 326-338. (https://doi.org/10.1111/adb.12200)

Moss BL, Elhammali A, Fowlkes T, Gross S, Vinjamoori A, Contag CH \& Piwnica-Worms D 2012 Interrogation of inhibitor of nuclear factor kappaB alpha/nuclear factor kappaB (IkappaBalpha/NF-kappaB) negative feedback loop dynamics: from single cells to live animals in vivo. Journal of Biological Chemistry 287 31359-31370. (https://doi. org/10.1074/jbc.m112.364018)

Nogueira L, Ruiz-Ontanon P, Vazquez-Barquero A, Lafarga M, Berciano MT, Aldaz B, Grande L, Casafont I, Segura V, Robles EF, et al. 2011 Blockade of the NFkappaB pathway drives differentiating glioblastoma-initiating cells into senescence both in vitro and in vivo. Oncogene 30 3537-3548. (https://doi.org/10.1038/onc.2011.74)

Ortiz LD, Syro LV, Scheithauer BW, Ersen A, Uribe H, Fadul CE, Rotondo F, Horvath E \& Kovacs K 2012 Anti-VEGF therapy in pituitary carcinoma. Pituitary 15 445-449. (https://doi.org/10.1007/ s11102-011-0346-8)

Ozes ON, Mayo LD, Gustin JA, Pfeffer SR, Pfeffer LM \& Donner DB 1999 NF-kappaB activation by tumour necrosis factor requires the Akt serine-threonine kinase. Nature 401 82-85. (https://doi. org/10.1038/43466)

Pikarsky E, Porat RM, Stein I, Abramovitch R, Amit S, Kasem S, Gutkovich-Pyest E, Urieli-Shoval S, Galun E \& Ben-Neriah Y 2004 NF-kappaB functions as a tumour promoter in inflammationassociated cancer. Nature 431 461-466. (https://doi.org/10.1038/ nature02924)

Place RF, Haspeslagh D, Hubbard AK \& Giardina C 2001 Cytokineinduced stabilization of newly synthesized I(kappa)B-alpha. Biochemical and Biophysical Research Communications 283 813-820. (https://doi.org/10.1006/bbrc.2001.4883)

Place RF, Haspeslagh D \&Giardina C 2003 Induced stabilization of IkappaBalpha can facilitate its re-synthesis and prevent sequential degradation. Journal of Cellular Physiology 195 470-478. (https://doi. org/10.1002/jcp.10262)

Rovillain E, Mansfield L, Caetano C, Alvarez-Fernandez M, Caballero OL, Medema RH, Hummerich H \& Jat PS 2011 Activation of nuclear factor-kappa B signalling promotes cellular senescence. Oncogene $\mathbf{3 0}$ 2356-2366. (https://doi.org/10.1038/onc.2010.611)

Sabatino ME, Petiti JP, Sosa L del V, Perez PA, Gutierrez S, Leimgruber C, Latini A, Torres AI \& De Paul AL 2015 Evidence of cellular senescence during the development of estrogen-induced pituitary tumors. Endocrine-Related Cancer 22 299-317. (https://doi.org/10.1530/ERC14-0333)

Sabatino ME, Grondona E, Sosa LDV, Mongi Bragato B, Carreno L, Juarez V, da Silva RA, Remor A, de Bortoli L, de Paula Martins R, et al. 2018 Oxidative stress and mitochondrial adaptive shift during pituitary tumoral growth. Free Radical Biology and Medicine 120 41-55. (https://doi.org/10.1016/j.freeradbiomed.2018.03.019)

Salminen A, Kaarniranta K, Haapasalo A, Hiltunen M, Soininen H \& Alafuzoff I 2012 Emerging role of p62/sequestosome-1 in the https://joe.bioscientifica.com

https://doi.org/10.1530/JOE-19-0506 (c) 2020 Society for Endocrinology Published by Bioscientifica Ltd. Printed in Great Britain 
pathogenesis of Alzheimer's disease. Progress in Neurobiology 96 87-95 (https://doi.org/10.1016/j.pneurobio.2011.11.005)

Sapochnik M, Fuertes M \& Arzt E 2017 Programmed cell senescence: role of IL-6 in the pituitary. Journal of Molecular Endocrinology $\mathbf{5 8}$ R241-R253. (https://doi.org/10.1530/JME-17-0026)

Satyanarayana A, Greenberg RA, Schaetzlein S, Buer J, Masutomi K, Hahn WC, Zimmermann S, Martens U, Manns MP \& Rudolph KL 2004 Mitogen stimulation cooperates with telomere shortening to activate DNA damage responses and senescence signaling. Molecular and Cellular Biology 24 5459-5474. (https://doi.org/10.1128/ MCB.24.12.5459-5474.2004)

Scheithauer BW, Gaffey TA, Lloyd RV, Sebo TJ, Kovacs KT, Horvath E, Yapicier O, Young Jr WF, Meyer FB, Kuroki T, et al. 2006 Pathobiology of pituitary adenomas and carcinomas. Neurosurgery 59 341-353; discussion 341-353. (https://doi.org/10.1227/01. NEU.0000223437.51435.6E)

Schramek D, Kotsinas A, Meixner A, Wada T, Elling U, Pospisilik JA, Neely GG, Zwick RH, Sigl V, Forni G, et al. 2011 The stress kinase MKK7 couples oncogenic stress to p53 stability and tumor suppression. Nature Genetics 43 212-219. (https://doi.org/10.1038/ng.767)

Tammela T, Sanchez-Rivera FJ, Cetinbas NM, Wu K, Joshi NS, Helenius K, Park Y, Azimi R, Kerper NR, Wesselhoeft RA, et al. 2017 A Wntproducing niche drives proliferative potential and progression in lung adenocarcinoma. Nature 545 355-359. (https://doi.org/10.1038/ nature22334)

Tilstra JS, Robinson AR, Wang J, Gregg SQ, Clauson CL, Reay DP, Nasto LA, St Croix CM, Usas A, Vo N, et al. 2012 NF-kappaB inhibition delays DNA damage-induced senescence and aging in mice. Journal of Clinical Investigation 122 2601-2612. (https://doi. org/10.1172/JCI45785)

Turner HE, Nagy Z, Esiri MM, Harris AL \& Wass JA 2000 Role of matrix metalloproteinase 9 in pituitary tumor behavior. Journal of Clinical Endocrinology and Metabolism 85 2931-2935. (https://doi.org/10.1210/ jcem.85.8.6754)

Tyagi N, Bhardwaj A, Singh AP, McClellan S, Carter JE \& Singh S 2014 p21 activated kinase 4 promotes proliferation and survival of pancreatic cancer cells through AKT- and ERK-dependent activation of NF-kappaB pathway. Oncotarget 5 8778-8789. (https://doi. org/10.18632/oncotarget.2398)

Vender JR, Laird MD \& Dhandapani KM 2008 Inhibition of NFkappaB reduces cellular viability in GH3 pituitary adenoma cells. Neurosurgery 62 1122-1127; discussion 1027-1128. (https://doi.org/10.1227/01. neu.0000325874.82999.75)

Wang W, Chen JX, Liao R, Deng Q, Zhou JJ, Huang S \& Sun P 2002 Sequential activation of the MEK-extracellular signal-regulated kinase and MKK3/6-p38 mitogen-activated protein kinase pathways mediates oncogenic ras-induced premature senescence. Molecular and Cellular Biology 22 3389-3403. (https://doi.org/10.1128/ mcb.22.10.3389-3403.2002)

Werner SL, Barken D \& Hoffmann A 2005 Stimulus specificity of gene expression programs determined by temporal control of IKK activity. Science 309 1857-1861. (https://doi.org/10.1126/science.1113319)

Werner SL, Kearns JD, Zadorozhnaya V, Lynch C, O'Dea E, Boldin MP, Ma A, Baltimore D \& Hoffmann A 2008 Encoding NF-kappaB temporal control in response to TNF: distinct roles for the negative regulators IkappaBalpha and A20. Genes and Development 22 2093-2101. (https://doi.org/10.1101/gad.1680708)

Xia Y, Padre R, Hurtado De Mendoza T, Bottero V, Tergaonkar V \& Verma I 2009 Phosphorylation of p53 by IкB kinase 2 promotes its degradation by $\beta$-TrCP PNAS 106 2629-2634. (https://doi. org/10.1073/pnas.0812256106)

Xia Y, Shen S \& Verma IM 2014 NF-kappaB, an active player in human cancers. Cancer Immunology Research 2 823-830. (https://doi. org/10.1158/2326-6066.CIR-14-0112)

Xu W, Li Y, Yuan WW, Yin Y, Song WW, Wang Y, Huang QQ, Zhao WH \& Wu JQ 2018 Membrane-bound CD40L promotes senescence and initiates senescence-associated secretory phenotype via NF-kappaB activation in lung adenocarcinoma. Cellular Physiology and Biochemistry 48 1793-1803. (https://doi.org/10.1159/000492352)

Yang H, Sun R, Ma N, Liu Q, Sun X, Zi P, Wang J, Chao K \& Yu L 2017 Inhibition of nuclear factor-kappaB signal by pyrrolidinedithiocarbamate alleviates lipopolysaccharide-induced acute lung injury. Oncotarget 8 47296-47304. (https://doi. org/10.18632/oncotarget.17624)

Received in final form 20 February 2020

Accepted 24 February 2020

Accepted Manuscript published online 24 February 2020 (c) 2020 Society for Endocrinology Published by Bioscientifica Ltd. Printed in Great Britain 